\title{
СТРАТЕГІЯ СТВОРЕННЯ ТА ОЦІНЮВАННЯ ФУНКЦІОНУВАННЯ СИСТЕМ УПРАВЛІННЯ ЯКІСТЮ МЕДИЧНОЇ ОСВІТИ. ПЕРШЕ ПОВІДОМЛЕННЯ. ПОСТАНОВКА ПРОБЛЕМИ
}

\author{
О. П. Мінцер, О. К. Толстанов, Г. В. Загорій, Т. П. Калита \\ Національна медична академія післядипломної освіти імені П. Л. Шупика
}

\begin{abstract}
Стаття присвячена питанням створення та функціонування систем управління якістю медичної освіти за стандартом ISO 9001. Обговорено проблеми оцінювання ефективності систем управління якістю медичної освіти, визначено причини їхньої неефективності. При цьому досліджується явище одночасного існування двох паралельних систем управління: формальної системи управління якістю та реальної системи прийняття управлінських рішень. Вводиться низка понять, у тому числі надійність і «працездатність» системи управління якістю, визначаються подальші завдання щодо обґрунтування показників функціонування системи управління якістю та механізмів її оцінювання.
\end{abstract}

Ключові слова: системи управління якістю, ISO 9001, медична освіта, післядипломна медична освіта, показники функціонування системи управління якістю, надійність та працездатність системи управління.

\section{СТРАТЕГИЯ СОЗДАНИЯ И ОЦЕНКИ ФУНКЦИОНИРОВАНИЯ СИСТЕМ УПРАВЛЕНИЯ КАЧЕСТВОМ МЕДИЦИНСКОГО ОБРАЗОВАНИЯ. ПЕРВОЕ СООБЩЕНИЕ. ПОСТАНОВКА ПРОБЛЕМЫ}

\author{
О. П. Минцер, А. К. Толстанов, Г. В. Загорий, Т. П. Калита \\ Национальная медицинская академия последипломного образования имени П. Л. Шупика \\ Статья посвящена вопросам создания и функционирования систем управления качеством медицинского обра- \\ зования по стандарту ISO 9001. Обсуждены проблемы оценки эффрективности систем управления качеством ме- \\ дицинского образования, обозначены причины их неэффективности. При этом исследуется явление одновремен- \\ ного существования двух параллельных систем управления: формальной системы управления качеством и реаль- \\ ной системы принятия управленческих решений. Вводится ряд понятий, в том числе надежность и \\ «работоспособность» системы управления качеством, определяются дальнейшие задачи по обоснованию показа- \\ телей функционирования системы управления качеством и механизмов ее оценки.
}

Ключевые слова: системы управления качеством, ISO 9001, медицинское образование, последипломное медицинское образование, показатели функционирования системы управления качеством, надежность и работоспособность системы управления.

\section{STRATEGY AND EVALUATION OF THE OPERATION OF QUALITY MANAGEMENT SYSTEMS MEDICAL EDUCATION. THE FIRST MESSAGE. PROBLEM FORMULATION}

\author{
O. P. Mintser, O. K. Tolstanov, G. V. Zagoriy, T. P. Kalyta \\ Shupyk National Medical Academy of Postgraduate Education
}

\begin{abstract}
The article is devoted to functioning of the quality management by ISO 9001 standard. The problem of inefficient and non-working systems is pointed out, the causes of their inefficiency are investigated. The phenomenon of simultaneous existence of two parallel management systems: formal quality management system and living systems of managerial decisions making is studied. To study this situation the measure of «efficiency of quality management system» is introduced; further tasks for creating indicators and mechanisms for its evaluation are defined.
\end{abstract}

Key words: quality management system, ISO 9001, medical education, postgraduate medical education, performance management system for quality, reliability and performance management system. 
Вступ. В останні десятиліття питання системного управління якістю набувають все більшої важливості як в Україні, так і в світі. Загострення глобальної конкуренції, зростання вимогливості споживачів, дефіцит багатьох категорій ресурсів змушують керівників підприємств і організацій приділяти більшу увагу питанням якості та управління нею. Однією з ключових тенденцій у цій галузі стало поширення сертифікації систем управління якістю на відповідність вимогам міжнародного стандарту ISO 9001. За оцінками самої ISO, серія стандартів ISO 9000 стабільно $\epsilon$ найбільш популярною з усіх стандартів, випущених цією організацією.

За ці роки стандарт ISO 9001 став основою для розроблення будь-яких інших стандартів на системи управління: як універсальних (екологічний менеджмент, менеджмент інформаційної безпеки), так і галузевих (виробництво медичного обладнання, фармацевтичне виробництво тощо). Не стала винятком і медична освіта. Більше того, питання управління медичною освітою з кожним роком набуває все більшого значення. В значній мірі це обумовлено незадоволеністю населення якістю надання медичної допомоги, що зростає в усьому світі. Підкреслимо, що фінансове забезпечення галузі хоча й має певне значення, але ж не вирішальне. Кількість лікарських помилок, наприклад, у США, де держава виділяє велике фінансування, налічує більше 100 тис. на рік і має тенденцію до збільшення.

Реформування медичної освіти (наприклад, впровадження Болонської системи чи проблемно-орієнтоване навчання) теж лише частково забезпечує покращання якості надання медичної допомоги. Складається враження, що явище інформаційно-технологічної сингулярності вже почало спостерігатися в підготовці лікарів і провізорів. Тому на перший план виходять проблеми саме медичної освіти.

Проблеми якості освіти піднімалися безліч разів. Можна вказати такі широко відомі міжнародні документи [1 - 4] стандарт ISO 9001; «Загальний менеджмент якості» - (TQM - Total Quality Management); Європейська мережа організацій гарантії якості у сфері вищої освіти (ENQA); Стандарти та Директиви для гарантії якості Вищої освіти в Європі; Стандарти ВФМО з забезпечення якості додипломної та післядипломної освіти, а також безперервного професійного розвитку лікарів (WFME Global Standards for Quality Improvement).

Проте стандарт ISO 9001, як правило, є першим кроком, «фундаментом» при приведенні систем менеджменту у відповідність до вимог будь-яких стан- дартів, а часто - і в цілому при побудові формалізованої системи менеджменту, в тому числі у системі післядипломної медичної освіти [5]. Підкреслимо, що цей стандарт входить й в систему державних стандартів України [1,2].

Таке використання стандарту призвело до його особливої ролі: часто він розглядається не як спосіб підтвердження здатності організації стабільно виконувати свої зобов'язання перед споживачами, і навіть не як опис однісї з цільових підсистем системи управління організацією, а як загальне керівництво 3 побудови дієвої та результативної системи управління. I саме така його роль робить особливо важливим його правильне розуміння і використання - адже будь-які помилкові трактування можуть призвести до того, що всі зусилля організацій щодо вдосконалення своєї системи управління на основі різних стандартів виявляться неефективними.

Мета. Обгрунтувати причини низької ефективності впровадження систем управління якістю, насамперед, в медичній освіті, та визначити шляхи подолання цієї проблеми. Дослідження феномену «непрацюючих» систем управління якістю: причин, способів діагностики та підвищення їх працездатності.

У першому повідомлені розглянуто основні концептуальні положення, в другому буде запропоновано метрику процесів оцінювання якості i, нарешті, у третьому - приклади побудови систем управління якістю згідно з стандартом ISO 9001.

Основна частина. Досить часто впроваджені та сертифіковані системи менеджменту якості є формальними, не використовуються вищим керівництвом для вирішення реальних проблем і не приносять організації належного ефекту. За оцінками фахівців, лише 30 \% сертифікованих систем у світі реально діють і відповідають букві і духу стандарту ISO 9001. Це явище має цілий ряд негативних наслідків:

- неефективні витрати ресурсів на створення i підтримку систем управління якістю, що не приносять суттєвої користі організаціям;

- неотримання організаціями переваг, які могло б принести дієве виконання вимог стандарту ISO 9001, наприклад - використання процесного менеджменту, проведення внутрішніх аудитів, реалізація коригувальних і запобіжних дій (при цьому зменшуються шанси нате, що відповідні ініціативи будуть впроваджені «за межами системи управління якістю» адже, на думку керівництва, вони вже працюють в організації, навіть якщо не приносять суттєвої користі); 
- створення негативного іміджу стандарту ISO 9001 серед споживачів, які в багатьох випадках не відчувають відмінності в якості продукції та послуг у підприємств, які мають і не мають сертифікат відповідності цьому стандарту;

- створення негативного іміджу стандарту ISO 9001 та управління якістю в цілому серед керівників організацій, сприйняття ними стандарту та сертифікації по ньому як формальності, що не має відношення до реального вдосконалення діяльності організації.

У масштабах світової економіки це призводить до того, що ефект від застосування систем управління якістю на сотнях тисяч організацій виявляється набагато нижчим від того, на який можна було б очікувати. Безумовно, якби всі ці організації дійсно системно і результативно займалися підвищенням задоволеності споживачів, вдосконаленням внутрішніх процесів, це могло б вплинути на глобальне підвищення якості життя.

Введемо основні визначення. Будемо вважати, що якість системи управління - це сукупність властивостей системи, що обумовлюють можливість иї використання для задоволення визначених відповідно до ï призначення потреб. При такому визначенні ключовим питанням є метрика оцінок. Найпростіша філософія, що пропонується в більшості наукових досліджень - коли кількісні характеристики властивостей системи визначаються для кожної системи окремо. Але чи можна запропонувати загальні показники, інваріантні відносно системи, що досліджується. В такому сенсі основним показником якості, безумовно, є надійність. По-суті, цей показник одночасно може слугувати мірою валідності критеріям системи, що вимірюються.

Будемо розуміти під надійністю властивість системи зберігати в часі у встановлених межах значення всіх параметрів, що характеризують здатність виконувати необхідні функції в заданих режимах і умовах застосування. Обгрунтовуючи на цій базі метрику системи управління якістю, можна відразу створити гіпотезу, що іiі елементами стануть дисперсійні характеристики, показники трендів показників, час досягнення цілей тощо.

Слід зауважити, що будування системи управління якістю, по-суті, являє собою деякий проект, що має свій термін існування. Корекція проекту можлива лише за певний час. Вочевидь, система управління якістю нерозривно зв'язана с процесами прийняття рішень [6]. Відповідно, певні зміни останніх потребують корекції чи повної зміни системи управління якістю.
Будемо вважати життєвим цииклом, проекту (Project Life Cycle) послідовність його фаз, що задається, виходячи з потреб управління проектом [7]. В рамках методології Інституту управління проектами (Project Management Institute), життєвий цикл проекту має 5 фаз [8]: ініціалізація (Initialization); планування (Planning); виконання (Executing); контроль і моніторинг (Controlling and Monitoring); завершення (Closing). В рамках подібного підходу важливим елементом метрики системи якості стає час.

Введемо також поняття працездатності системи управління якістю. Будемо називати систему управління якістю працездатною, якщо в її рамках керівники організації приймають адекватні управлінські рішення, спрямовані на реалізацію організаційної місії і стратегії. Головне, що ці рішення в рамках визначеної стратегії та визначеної метрики забезпечують і контролюють рух організації в заданому напрямку. В такому розумінні метрики можуть створити відхилення показників функціонування системи управління якістю від траєкторії, що раніше задана.

Формально складовими елементами працездатності системи в рамках стандарту можуть бути такі:

- визначення та погодження пріоритетів розвитку організації здійснюється в рамках системи управління якістю;

- інформація, що використовується для прийняття управлінських рішень, збирається й узагальнюється в рамках системи управління якістю;

- заходи, на яких розглядається й аналізується зібрана інформація, є частиною системи управління якістю;

- оформлення прийнятих рішень та звітування про їх виконання здійснюється у формах, прийнятих у системі управління якістю;

- стандартизація змін до порядку виконання робіт, пов'язаних із впровадженням управлінських рішень, відбувається шляхом розробки / перегляду документів системи управління якістю.

- зміна задекларованих стратегічних тверджень i політики у сфері якості;

- об'єднання задекларованих стратегічних тверджень (або деяких із них) в один документ, що й буде політикою в сфері якості;

- розроблення окремої політики в галузі якості 3 чітким визначенням їі місця в існуючій системі стратегічних тверджень, взаємозв'язок із ними.

Однією з можливих головних причин низької ефективності систем управління якістю $є$ існування в організації двох паралельних систем управління. 
3 одного боку, це формальна система управління якістю, яка задокументована відповідно до вимог стандарту ISO 9001 (або інших системних стандартів), перевіряється в ході внутрішніх аудитів і демонструється зовнішнім аудиторам 3 метою отримання сертифіката. Як правило, ця система створюється в рамках окремого проекту з побудови системи управління якістю. 3 іншого боку-реальна система управління, в рамках якої керівники організації приймають тривіальні управлінські рішення та забезпечують їх виконання. Вона може бути не оформлена документально і не відповідати жодному стандарту, але вона існує первинно в будь-якій організації. Адже будь-який керівник знає, як саме він звик керувати організацією: які дії він робить, якщо хоче змінити щось в їі роботі, якій інформації він довіряє і як їі враховувати при прийнятті рішень, які саме вимоги він висуває до тієї чи іншої роботи тощо. А саме такі звички, уявлення та погляди керівників (особливо першого керівника організації) й утворюють систему управління, яку ми надалі будемо називати «реальною».

Зрозуміло, що відмінності між цими двома системами є факторами ризику того, що система управління якістю буде непрацюючою, навіть якщо вона успішно пройшла сертифікацію. Будь-яка формалізована система управління, в тому числі система управління якістю, буде по-справжньому працювати, використовуватися керівництвом для прийняття дійсних управлінських рішень тільки якщо вона збігається з реальною системою управління.

Підкреслимо, що можливою причиною створення подібних відмінностей є те, що розробникам системи простіше розробляти систему управління якістю «з чистого аркуша», використовуючи при цьому типові напрацювання, ніж розбиратися в існуючій системі управління організацією, шукати підходи, адаптовані до неї, або змінювати їі. Аналогічно, і з точки зору аудиторів у багатьох випадках простіше перевірити «чисту» систему управління якістю, що не інтегрована в загальну систему управління, структуровану за стандартом, та ще й побудовану з використанням типових рішень. Набагато складніше виокремлювати їі із загальної системи управління, організованої відповідно до стратегії організації та iii специфіки. Наприклад, стандарт містить вимогу про наявність в організації цілей у сфері якості. Найпростіший спосіб виконати цю вимогу - розробити документ $з$ такою назвою. Можна також спробувати розібратися в існуючій системі управління та знайти в організації вже сформульовані цілі їі розвитку в рамках стратегії, бюджету, програмно-цільових наказів. Після цього можна прийняти різні рішення, наприклад:

- визначити, що функції документованих цілей у сфері якості виконує один 3 існуючих документів (можливо, доповнивши або переробивши його);

- об' єднати наведені в різних документах кількісні цілі в один документ, який і буде виконувати функції цілей у сфері якості;

- розробити окремі документовані цілі у сфері якості, але при цьому чітко визначити їх місце в існуючій системі кількісних цілей, взаємозв'язок з іншими документами, які їх містять.

Але який би варіант не був вибраний, це однозначно краще, ніж розробляти цілі у сфері якості, ігноруючи при цьому існуючу систему управління. Адже такий підхід найчастіше призводить до того, що ці цілі залишаються формальними і практично не впливають на роботу організації.

Можливо, при проведенні такого аналізу наявних кількісних цілей виявиться, що вони не є погодженими між собою, не відповідають вимогам стандарту ISO 9001 (наприклад, не визначені цілі щодо якості продукції та задоволеності споживачів, не для всіх цілей заплановані заходи з їх досягнення). Це може вимагати доповнення цілей, їх взаємоузгодження, удосконалення процедури їх перегляду тощо. Це може вимагати зміни підходів до бюджетування, стратегічного планування тощо. Саме на таких проблемах «реальної» системи менеджменту варто робити акцент при їі приведенні у відповідність до вимог стандарту, і саме їх рішення може принести користь організації.

Наявність двох окремих систем управління, безумовно, створює великі проблеми в діяльності організації. При конфлікті систем, коли висунуті ними вимоги будуть суперечливими, швидше за все персонал віддаватиме перевагу традиційній системі управління, а система управління якістю залишиться непрацюючою (точніше, вона буде працювати тільки в тих галузях, в яких вона збігається з загальною системою управління).

Для аналізу описаної ситуації застосуємо поняття працездатності системи управління якістю медичної освіти. Зрозуміло, що рівень працездатності системи управління якістю визначає ступінь збігу критеріїв в основних процесах в теоретично розробленій системі і в реальній системі управління організацією.

Розбіжність між системою управління якістю та загальною системою управління може бути обумовлена також тим, що не забезпечена конкордатність між: 
- сформульованою політикою у сфері якості та системою стратегічних тверджень організації (місія, бачення, стратегічні пріоритети тощо);

- окремими планами якості та загальностратегічними і оперативними планами розвитку організації;

- окремо розробленими документами системи управління якістю (наприклад, методики процесів) i традиційними документи, що регламентують порядок виконання різних робіт в організації (наприклад, інструкції, положення, процедури тощо);

- спеціальними звітами про функціонування окремих процесів, системою управління якістю в цілому і загальними звітами про різні аспекти функціонування організації (включаючи фінансовий аналіз);

- спеціальними заходами 3 аналізу функціонування окремих процесів, системою управління якістю в цілому і спільними заходами з аналізу роботи організації (наприклад, директорат, технічні ради, оперативні наради тощо);

- системою управління документацією та записами, що відноситься до документів системи управління якістю, а також традиційною системою документообігу.

Безумовно, це не означає, що відповідні складові існуючої системи управління організацією можуть бути застосовані у вигляді «як є», без глибокого аналізу і змін. Навпаки, головним завданням проекту 3 побудови системи управління якістю якраз і може бути їх систематизація, вдосконалення, розширення сфери їх застосування, зокрема шляхом приведення у відповідність до вимог стандарту ISO 9001. Наприклад, коло питань, які розглядаються на заходах за участі вищого керівництва, може потребувати розширення i включення до нього результатів внутрішніх аудитів, даних про задоволеність споживачів тощо.

Нарешті, неможливість домогтися прогнозованих результатів може бути пояснена вкрай складною системою організації освіти, а головне - невизначеністю метрики в оцінці результатів навчання. Формально якість вищої освіти лікарів та провізорів віддзеркалює рівень здобутих особою знань, умінь, навичок тощо, що відображає компетентність фахівців відповідно до стандартів вищої освіти [9]. Але ж, в дійсності, завдання вищої школи не зводиться тільки до освітніх послуг. Продуктом освіти $є$ соціальна якість людини в цілому, тобто особистість у всьому багатстві ії проявів, включаючи професіоналізм [10]. Відповідно, реальна якість освіти може бути перевірена значно пізніше завершення базового навчання в ВНЗ чи на етапі післядипломної освіти.
Існує необхідність підкреслити особливості системи оцінки якості післядипломної освіти технологів фармацевтичного виробництва та провізорів. Головною відмінністю подібної системи є більш широке використання трансдисциплінарних технологій навчання. їх суть полягає в необхідності використання в процесі підготовки фахівців таких дисциплін, котрі в медичних навчальних закладах зазвичай не практикуються, наприклад математичне моделювання, нанотехнології тощо. Визначити якість передачі знань в таких випадках досить складно. Так само нелегко здійснити постійний аудит подібного процесу.

Розглянемо тепер на концептуальному рівні зв'язок між поняттями працездатності системи управління якістю і іï результативністю та ефективністю. Вже підкреслювалося, що система управління (в тому числі - система управління якістю) є результативною, якщо прийняті в іiі рамках управлінські рішення є результативними і забезпечують досягнення цілей, що стоять перед організацією. Аналогічно, система управління є ефективною, якщо прийняті в iii рамках управлінські рішення є ефективними і забезпечують прийнятне співвідношення між досягнутими результатами та використаними ресурсами.

Вочевидь, якщо система управління якістю не $є$ працездатною, то вона не може бути ні результативною, ні ефективною: якщо в рамках системи не приймаються реальні управлінські рішення, то недоречно говорити про їх результативність або ефективність.

При цьому можлива ситуація, коли діяльність організації в цілому є результативною (ефективною) коли керівництво приймає результативні (ефективні) рішення. Але ці результати ніяк не залежать від існування формалізованої системи управління, вони досягаються незалежно від неї, а відповідні рішення приймаються за їі межами. Також можлива ситуація коли система є працездатною, але не результативною: керівництво реально працює 3 нею і приймає рішення в її рамках, але ці рішення з різних причин не дозволяють організації досягти своєї мети. Наприклад, вони можуть бути неточними, недостатніми, несвоєчасними тощо.

Причини непрацездатності системи управління якістю можуть бути різні:

- система управління якістю є недосконалою, вона не спрямована на прийняття результативних та ефективних рішень і тому керівники організації не бачать можливості користуватися нею (проблема в системі); 
- керівники є недостатньо кваліфікованими, щоб оцінити систему управління якістю та переваги їі використання для прийняття рішень (проблема в керівниках);

- система управління якістю $є$ незручною для керівників, не збігається зі звичною для них схемою прийняття рішень (проблема в співвідношенні системи і керівників).

Але всі ці причини можуть бути об'єднані в одну загальну: формалізована система управління якістю не відповідає вимогам та очікуванням керівництва організації щодо того, як вони повинні приймати рішення і забезпечувати їх виконання.

\section{Література}

1. Системи управління якістю. Основні положення та словник термінів (ISO 9000:2005, IDT) : ДСТУ ISO 9000:2007. - [Чинний від 2008-01-01]. - К. : Держспоживстандарт України, 2008. - 29 с. - (Національний стандарт України).

2. Системи управління якістю. Вимоги (ISO 9001:2008, IDT): ДСТУ ISO 9001:2009. - [Чиннийвід 2009-09-01].

- К. : Держспоживстандарт України, 2009. - 26 с. - (Національний стандарт України).

3. World Federation for Medical Education. The Edinburgh Declaration. History of the First Forty Years, 1972-2012/ H. Karle. - 30 с. - Режим доступу: http://wfme.org/ docmnents/about-wfine/79-wfine-history-of-the-firstforty-years-1972-2012/file.

4. Международные стандарты ВФМО по улучшению качества в медицинском образовании. Европейская спецификация. Рабочая группа по обеспечению качества. Копенгаген : Всемирная организация здравоохранения, 2007. - 82 c.

5. Последипломное медицинское образование Международные стандарты ВФМО улучшения качества. - Копен-
Висновки. 1. Потребує найскорішого визначення метрика систем управління якістю медичної освіти.

2. Запропоновано критерії надійності та працездатності систем управління якістю освіти.

3. Непрацездатність систем управління якістю $є$ суттєвою проблемою як для організацій, так і для економічної системи в цілому. Необхідно створити систему оцінювання рівня працездатності систем, визначити показники такого оцінювання та алгоритм їх вимірювання; розробити механізми для діагностування причин та галузей низької працездатності систем, обгрунтувати напрями їі підвищення; визначити рекомендації щодо шляхів підвищення працездатності систем.

гаген : Всемирная организация здравоохранения, 2003. $22 \mathrm{c}$.

6. Improving clinical practice using clinical decision support systems: a systematic review of trials to identify features critical to success/K. Kawamoto, C. A. Houlihan, E. A. Balas, D. F. Lobach//BMJ. -2005 . -№ 330 (7494). - P. 765-773. 7. Хелдман К. Профессиональное управление проектами/К. Хелдман. - М. : Бином, 2005. - 517 е.: ил.

8. Cooke-Davies T. The maturity of project management in different industries / T. Cooke-Davies, A. Arzymanow // International Journal of Proj ect Management. - 2003 . - № 21 (6).-P. $471^{\wedge} 178$.

9. Оценка качества высшего образования в Украине / В. С. Добряк, М. С. Мазорчук, Н. С. Бакуменко // Якість технологій та освіти. - 2013. - № 4. - С. 67-73.

10. Корнєєва ЈI. Якість освітніх послуг з позицій міжнародних стандартів серії ISO 9000:2000 / Л. Корнєєва, М. Сіницький // Освіта і управління. - 2006. - Т. 9, № 1. C. 87-90. 